\title{
THE INFLUENCE OF METEOROLOGICAL CONDITIONS DURING TRADITIONAL SMOKING ON POLYCYCLIC AROMATIC HYDROCARBON CONTENT IN TRADITIONAL POLISH PORK HAM
}

\author{
- Research paper - \\ Karolina CHOROSZY*, Krzysztof TERESZKIEWICZ \\ Rzeszów University of Technology, The Faculty of Management, Department of Computer \\ Engineering in Management, Powstańców Warszawy 8, 35-959 Rzeszów, Poland; \\ tel. (17) 8651089
}

\begin{abstract}
The aim of the study was to examine the influence of meteorological conditions observed during the process of traditional smoking on polycyclic aromatic hydrocarbon content in traditional Polish pork ham. The material of the study comprised traditional Polish pork ham, one of the most frequently purchased and consumed meat products in Poland. The analysed ham was smoked with the traditional method using beech chips and pieces. Smoking time was four hours. During laboratory research the basic chemical composition of the product was examined. Using the HPLC method, the level of 15 selected Polycyclic Aromatic Hydrocarbons (PAHs). The obtained results show that the level of selected polycyclic aromatic hydrocarbons in the examined material depended on atmospheric pressure and relative air humidity. Atmospheric pressure significantly influenced the content of benzo(b)fluoranthene, benzo(a)anthracene and indeno(c,d)pyrene. Relative humidity impacted the absorption level of 5-methylchrysene, benzo(a)pyrene, benzo(b)fluoranthene, benzo(g,h,i)perylene, benzo(j)fluoranthene and indeno(c,d)pyrene. An influence of air temperature during the smoking process on PAHs content in the product was not observed. The results indicate that traditional smoking should be conducted under conditions of high relative humidity - ideally above $75 \%$, and high atmospheric pressure above $1000 \mathrm{hPa}$.
\end{abstract}

Keywords: traditional smoking, polycyclic aromatic hydrocarbons, air temperature, atmospheric pressure, relative air humidity, quality management.

\section{INTRODUCTION}

Smoking is an old and popular method of meat preservation. It is still used nowadays mainly in the sectors of food processing where traditional methods of production are applied (Bagnowska et al., 2011; Kołakowski et al., 2012; Rey-Salgueiro et al., 2008a,b; Rozentāle et al., 2015). Traditional smoking improves the taste and organoleptic values of products, lending them a specific colour, smell and texture (Hitzel, Pöhlmann, Schwägele, Speer and Jira 2012). Smoking is particularly important in the production of meat products. According to general principles, traditional smoking is conducted in smoking chambers, where the hardwood of deciduous trees with an appropriate level of humidity is burnt as the source of smoke and heat. The processed products are located above or at a certain distance from the

Received: 02.03.2021

Accepted in revised form: 15.09.2021 smoke generator in which the wood is burnt (Choroszy and Tereszkiewicz, 2020; Rozentāle et al., 2015; Migdał, 2014; Kołakowski et al., 2012).

The smoke used in traditional smoking is a product of incomplete combustion, comprising numerous ingredients, such as phenols, formaldehydes, organic acids and polycyclic aromatic hydrocarbons (PAHs) (Ekomy, Bruneau, Mbega i Aregba, 2013). Many authors proved that smoking leads to the contamination of the food with compounds such as $\mathrm{N}$-nitrosamines, bisphenol A, heterocyclic aromatic amins, $\beta$-carbolines, and especially with polycyclic aromatic hydrocarbons that may pose a potential threat due to their toxic and carcinogenic impact (Ghasemzadeh-Mohammadi, 2012; Djinovic et al., 2008; Shrestha et al., 2015; Arias et al., 2010; Pongpiachan, 2015; Rey-Salguerio et al., 2009a; Rey-Salguerio et al., 2009b; Yebra-Pimentel et al., 2012; Yerba-Pimentel et al., 2014, Ledesma Rendueles and Díaz, 2017, Li, 2016). The content of PAHs in food products may cause serious health problems and is therefore undesirable (Alomirah et

*Corresponding author. E-Mail address: choroszy@prz.edu.pl 
al., 2010; Alomirah et al., 2011; Rey-Salguerio et al., 2009a; Guo et al., 2009, Li et al., 2016, Sapota, 2002). For these reasons, maximum acceptable levels of contamination with PAHs in smoked products were introduced in the European Union. These matters are discussed in the Regulation (EC) No. 835/2011 regarding the control of contamination of food products. The Regulation No. 835/2011 of $19^{\text {th }}$ August 2011 changed the Regulation No. 1881/2006 setting maximum acceptable levels for PAHs in food products and introduced limits concerning the content of benzo(a)pyrene and the sum of four PAHs (B(a)P, $\mathrm{B}(\mathrm{a}) \mathrm{A}, \mathrm{B}(\mathrm{b}) \mathrm{F}, \mathrm{CHR}$ ) to $5,0 \mu \mathrm{g} / \mathrm{kg}$ and $30,0 \mu \mathrm{g} / \mathrm{kg}$, respectively, for smoked meat and smoked meat products and smoked fish and smoked fish products (with exceptions). After two years, that is since $1^{\text {st }}$ September 2014, these leves were further decreased to $2,0 \mu \mathrm{g} / \mathrm{kg}$ and $12,0 \mu \mathrm{g} / \mathrm{kg}$, respectively.

Despite attempts at controlling the process of wood thermic pyrolysis applied during smoking to decrease the level of PAHs, a significant content of these compounds, which are considered dangerous to consumers' health, is still found in the smoke ( $\mathrm{Li}$ et al., 2016; Lee et al., 2016; Fasano et al., 2016; Rozentāle et al., 2015). Numerous factors impact the contamination level of products with PAHs. According Ledesma et al. (2015; 2014), the most important factors comprise the type of fuel, time and temperature of wood pyrolysis, smoke opacity,

\section{MATERIALS AND METHODS}

\section{Smoking process}

The material of the study comprised traditional Polish pork ham produced in a company specializing in the production of traditional products, located in the south-east of Poland. The semimembranosus muscle - the part obtained from the pork ham and technologically prepared for smoking - was used in the production of the product. In order to obtain and consolidate specific organoleptic features the product selected for the analysis was smoked using the traditional method for 4 hours. The smoke was produced in the smoke generator located around $100 \mathrm{~cm}$ from the chember by the pyrolysis of air-dried wood chips and pieces. Beech wood with the stable humidity level of 10$12 \%$ was used in the smoking process. The smoking process in the smoke generator of the chamber was performed by means of incandescent burning; the average temperature was around $675^{\circ} \mathrm{C}$. The temperature of the smoke generator was measured with a 36798 micro IR-200 RIDGID infrared thermometer. The aerosol of the smoke was directed airflow, chamber construction, type of smoking: direct or indirect, the distance between the product and the heat source, cleanliness of the equipment and the chamber. Based on the previous sources, the contamination of products with PAHs may be systematized according to the type of smoking (Ledesma et al., 2015,2014), type of fuel used to produce the smoke (Ledesma et al., 2015,2014), duration of smoking (Li et al., 2016, Ledesma et al., $2015,2014)$, the microclimate in the chamber, and primarily - the temperature of the product during smoking (Li et al. 2016).

There is a lack of research concerning PAH content in meat products depending on meteorological conditions, such as air pressure, relative humidity and temperature. According to sources (Pohlmann et al. 2012, Šimko 2005 and Rozentāle et al. 2015, Škaljac et al. 2014), these conditions may significantly influence the reactions during heterogenic smoking and the amount and composition of the products of combustion (thermal decomposition). An attempt at assessing the influence of microclimatic conditions during smoking and their relation to the accumulation of PAHs in ham may be a significant contribution to the knowledge and practice of traditional smoking. The aim of the study was to analyse PAH content depending on meteorological conditions during the smoking process using the example of traditional Polish pork ham.

to the smoking chamber where the product was placed via the inlet channel.

A total of 70 samples of the product was obtained for further analysis. $2 \mathrm{~kg}$ samples in the form of a whole baton of ham were collected 10 times with weekly intervals immediately after thermal processing and cooling of the product. The samples were collected according to the PN-EN ISO 15753 regulations. The samples were packed in sterile and cooled containers and were transported to the laboratory. To obtain laboratory samples the material was minced and mixed using a magnetic mixer in order to homogenate the sample. The material was then packed to sterile glass containers, $20 \mathrm{~g}$ in each sample, and stored at a temperature of $-25^{\circ} \mathrm{C}$ (Choroszy and Tereszkiewicz, 2020).

\section{Measurement of basic chemical composition Water content was measured according to PN-ISO 1442:2000. Samples of $5 \mathrm{~g}$, with an accuracy up to $0.0001 \mathrm{~g}$, were weighed into a previously dried and weighed weighing bottle with sand. The sample was then dried to a solid mass at a temperature of $105 \pm$ $1^{\circ} \mathrm{C}$. Following each stage of drying, the sample was}


transferred to an exicator in order to cool it down to room temperature, and then it was measured with an accuracy up to $0.0001 \mathrm{~g}$. Next, the percentage content of water was measured.

Fat content was measured by means of the Soxhlet method in accordance with PN-ISO 1444:2000. Samples of $5 \mathrm{~g}$, weighed with an accuracy up to $0.0001 \mathrm{~g}$, were dried at a temperature of $105^{\circ} \mathrm{C}$ for 3 hours. The material obtained in this way underwent extraction in a VELP Ekstraktor SER $148 / 3$ apparatus by means of dehydrated and peroxide-free light petroleum. The extracted fat was measured with an accuracy up to $0.0001 \mathrm{~g}$. Next, the percentage content of fat was measured.

Protein content was measured by means of Kjeldahl's method according to PN-75/A04018/Az3:2002. Samples of $1.5 \mathrm{~g}$, with an accuracy up to $0.0001 \mathrm{~g}$, were weighed to a mineraliser flask. The samples were then mineralised in a DK 8 VELP mineraliser block, in $\mathrm{H}_{2} \mathrm{SO}_{4}$ environment with catalysers speeding up the process of mineralisation, at a temperature of $380 \div 420^{\circ} \mathrm{C}$, until the liquid in the flask changed to a green colour. The distillation was conducted in a UDK 129 VELP water distillation apparatus in a $33 \% \mathrm{NaOH}$ solution. The obtained distillate was automatically titrated in a Titroline Easy Titrator apparatus with $0.1 \mathrm{M} \mathrm{HCl}$ solution, until a solution with a $\mathrm{pH}$ of 4.6 was obtained. Next, the protein content (in \%) was calculated based on the percentage content of nitrogen.

Sodium chloride content was measured by means of Mohr's method according to PN-75/A-82112. Samples of $2 \mathrm{~g}$, weighed with an accuracy up to $0.0001 \mathrm{~g}$, were transferred to a $250 \mathrm{~cm}^{3}$ weighing flask. Next, the sample was covered with $50 \mathrm{~cm}^{3}$ of hot distilled water, mixed and cooled. $5 \mathrm{~cm}^{3}$ of 0.1 $\mathrm{M} \mathrm{NaOH}$ solution was added to the flask and filled with distilled water up to the measuring point. The mixture was then sipped, with $25 \mathrm{~cm}^{3}$ of the filtrate measured to a conical flask with a few drops of $5 \%$ $\mathrm{K}_{2} \mathrm{CrO}_{4}$ solution. Such samples were titrated with $0.1 \mathrm{M} \mathrm{AgNO}_{3}$ solution until a red-brown hue was obtained. The result of the titration constituted the basis for the calculation of the percentage content of sodium chloride.

\section{Determination of PAH content}

PAH content was determined with the use of extraction and purification method followed by the liquid chromatography (HPLC) method, as described by Choroszy and Tereszkiewicz (2020).

\section{The measurement of meteorological conditions}

The measurement of meteorological conditions was conducted during the smoking of each batch of the product from which samples were obtained. The measurements were performed with an LB-707 thermometer - barometer - hygrometer, installed 10 $\mathrm{m}$ from the smoking place. An LB-707 apparatus is a measurement microcomputer which handles external temperature, humidity and pressure probes. The temperature, relative humidity and atmospheric pressure were monitored in this way. The parameters of temperature, humidity and atmospheric pressure were recorded at 15-minute intervals. The mean arithmetic average calculated from these measurements was the basis for further analysis.

\section{Statistical analysis}

The numerical material obtained from laboratory measurements underwent statistical analysis using Statistica 12 software. The $\alpha=0.05$ level of statistical significance was described in the verification of the hypothesis. The statistical analysis was conducted in three stages. In the first stage, the hypotheses concerning the identity of the compared empirical decompositions with the ordinary decomposition (chi-squared test) and variance equality in these decompositions (Hartley's test) were verified. The results showed that all the empirical decompositions comply with the normal decomposition, and the variances of the compared decompositions do not differ significantly (Dobosz, 2001; Mynarski, 2003). In the second stage, the values of Pearson's correlation coefficients were measured, showing the correlations between the average level of temperature, relative humidity and atmospheric pressure during smoking and the average content of individual hydrocarbons in the analysed ham. The significance of the " $r$ " coefficient was measured using the Student's t-test (Dobosz, 2001; Mynarski, 2003). In the third stage, the results of the research underwent a single- (ANOVA) and two-factor (MANOVA) variance analysis using the F FisherSnedecor test. Before variance analysis was performed, the quantitative variables depicting the level of atmospheric pressure and relative air humidity were converted to qualitative variables. Atmospheric pressure was divided into two ranges: below $1000 \mathrm{hPa}$ and above $1000 \mathrm{hPa}$. Relative air humidity was divided into three ranges: below $50 \%$, 50-75\%, and above 75\% [Mynarski, 2003]. 


\section{RESULTS AND DISCUSSION}

The basic chemical composition of the examined product is presented in Table 1 . The average water content in traditional Polish pork ham was $68.10 \%$, and standard deviation was $3.20 \%$. This is where the highest value of standard deviation for all the chemical components examined in the product was observed. The average fat content in traditional Polish pork ham was at the level of $2.98 \%$. Standard deviation for fat was $0.93 \%$. The results for the average protein content in traditional Polish pork ham were high and were at an average level of $26.03 \%$. Simultaneously, standard deviation for this value was $2.53 \%$. Sodium chloride content was $3.83 \%$ - it was the most stable chemical component $(\mathrm{Sd}=0,61 \%)$.

Variance analysis of PAH content in traditional Polish pork ham depending on meteorological conditions during smoking was preceded by an analysis of Pearson's correlation coefficients, showing the correlation between the average level of temperature, relative air humidity and atmospheric pressure during smoking and the relative content of individual PAHs in meat products. These results are presented in Table 2. A few reports on the influence of meteorological conditions (Ledesma et al., 2015) show that dry air during smoking facilitates an increase in the temperature in the smoking chamber, which enhances faster air circulation and flow of smoke from the smoke generator to the smoked products. In a different study, Ledesma et al. (2015) show that the temperature and humidity in the chamber during traditional smoking depend on unpredictable and changeable weather conditions. A similar observation was made by Parol et al. (2014), who observed significant fluctuation in hydrocarbon content in the samples of identical ham (from 8.29 to $13.97 \mu \mathrm{g} / \mathrm{kg}$ of fluoranthene, and from 13.19 to $8.15 \mu \mathrm{g} / \mathrm{kg}$ of pyrene), and who explain this fact by changeable atmospheric conditions, such as atmospheric pressure, wind strength, access and flow of air in the smoking chamber during smoking. The cited authors do not present detailed results which would show the direction and strength of the influence of meteorological conditions on the contamination of smoked products with hydrocarbons. Pohlmann et al. (2012) make a hypothesis that the level of external atmospheric pressure determines the intensity of polycyclic aromatic hydrocarbon contamination during smoking. In other studies (Šimko, 2005; Rozentāle et al., 2015), it was suggested that the high PAH concentration in traditionally smoked products of a small volume may be caused by environmental conditions such as air humidity and temperature. According to the sources mentioned, the presence of polycyclic aromatic hydrocarbons in meat products undergoing smoking may be to a certain extent conditioned by the microclimate in which smoking is conducted. The sources, however, do not provide adequate information about the role of atmospheric pressure, temperature and relative air humidity in the shaping of the PAH profile in smoked products. A significantly greater attention has been given so far to the influence of the microclimate inside the smoking chamber on the PAH profile (Šimko, 2005; Škaljac et al., 2014; Rozentāle et al., 2015).

A detailed control of atmospheric conditions in which smoking is conducted, undertaken in the present study, made it possible to obtain original information on the role of atmospheric pressure, temperature and relative air humidity on the contamination of meat products with PAHs.

The obtained results show that atmospheric pressure had an influence on the accumulation of benzo(b)fluoranthene, chrysene and indeno(c,d)pyrene in the examined product. Relative humidity decided about the absorption of 5-methylchrysene, benzo(a)pyrene, benzo(b) fluoranthene, benzo(g,h,i)perylene, benzo(j) fluoranthene and indeno(c,d)pyrene.

Table 1. Chemical composition of traditional Polish pork ham smoked using the traditional method

\begin{tabular}{ccc}
\hline Parameter & $\bar{x}[\%]$ & $S_{d}$ \\
\hline water & 68,10 & 3,20 \\
\hline fat & 2,98 & 0,93 \\
\hline protein & 26,09 & 2,53 \\
\hline sodium chloride & 3,83 & 0,61 \\
\hline
\end{tabular}

Table 2. Correlation between meteorological conditions during smoking and PAH content in traditional Polish pork ham smoked using the traditional method

\begin{tabular}{|c|c|c|c|}
\hline & Pressure & Humidity & Temperature \\
\hline & \multicolumn{3}{|c|}{ "r" correlation coefficient } \\
\hline $5-$ & 0,002 & $-0,320 *$ & 0,060 \\
\hline \multicolumn{4}{|l|}{ MeCHR } \\
\hline $\mathrm{BaA}$ & $-0,018$ & $-0,024$ & $-0,036$ \\
\hline $\mathrm{BaP}$ & $-0,035$ & $-0,222 *$ & $-0,100$ \\
\hline $\mathrm{BbF}$ & $-0,170 *$ & $-0,150 *$ & $-0,028$ \\
\hline $\mathrm{BcFl}$ & 0,059 & 0,072 & 0,091 \\
\hline BghiP & $-0,019$ & $-0,257 *$ & 0,031 \\
\hline $\mathrm{BjF}$ & 0,086 & $-0,191 *$ & $-0,049$ \\
\hline $\mathrm{BkF}$ & $-0,028$ & $-0,079$ & $-0,018$ \\
\hline CHR & $-0,161 *$ & 0,046 & $-0,034$ \\
\hline IcdP & $-0,179 *$ & $-0,216 *$ & $-0,088$ \\
\hline
\end{tabular}


The calculated significant correlation coefficients assumed negative values (Table 2), meaning that together with an increase in atmospheric pressure or relative humidity the percentage of these hydrocarbons in the examined product decreased. The study shows that from the analysed parameters, only air temperature outside of the smoking chamber during the smoking process did not have a significant influence on the accumulation of polycyclic aromatic hydrocarbons. Previous studies, however, indicate that the temperature inside the smoking chamber is one of the main factors influencing the contamination of smoked products with PAHs (McGrath et al., 2003; StumpeViksna et al., 2008; Rose et al., 2015, McMurry, 2005; Lendesma et al., 2014; Rozentāle et al., 2015; Singh et al., 2016). This relation is particularly visible during smoking with hot smoke. The temperature in the smoke generator is the parameter playing the most significant role in the accumulation of polycyclic aromatic hydrocarbons in smoked products. It ranges from $500^{\circ} \mathrm{C}$ to $1000^{\circ} \mathrm{C}$. The amount of PAHs which arises during wood pyrolysis in the smoke increases linearly with an increase in the smoking temperature. This process occurs at temperatures between $400 \div 1000^{\circ} \mathrm{C}$ (Tóth, Blaas, 1972a,b; Šimko, 2002), which was confirmed by Djinovic et al. (2008).

Results concerning the content of benzo(a) anthracene and chrysene, considered light PAHs, in traditional Polish pork ham depending on atmospheric conditions are presented in Tables 3 and 4. Two-factor variance analysis shows that benzo(a)anthracene content in the examined product is not correlated with a simultaneous influence of the analysed factors. The single-factor variance analysis performed here shows that at pressure above $1000 \mathrm{hPa}$ the influence of humidity on benzo(a)anthracene content is statistically significant $(\mathrm{F}=3.34 ; \mathrm{p}=0.035)$ (Table 3$)$. The influence is visible when relative air humidity exceeded 50\% (3.87 $\mu \mathrm{g} / \mathrm{kg})$. At high humidity (50$75 \%$ ) and the same pressure, the contamination decreased to the level of $1.52 \mu \mathrm{g} / \mathrm{kg}$. An increase in the relative air humidity above $75 \%$ led to a further insignificant $0.18 \mu \mathrm{g} / \mathrm{kg}$ increase in the contamination. At pressure above $1000 \mathrm{hPa}$ a decrease in $\mathrm{BaA}$ content occurred with an increase in air humidity (from $4.31 \mu \mathrm{g} / \mathrm{kg}$ to $2.61 \mu \mathrm{g} / \mathrm{kg}$ ), but these changes were not statistically confirmed.

Further analysis of light PAHs concentration (Tab. 4) shows that CHR level in the examined ham statistically significantly depended on air humidity during smoking. At humidity below $50 \%$ and pressure above $1000 \mathrm{hPa}$, average CHR concentration exceeded $5.00 \mu \mathrm{g} / \mathrm{kg}$, while at higher humidity the contamination was nearly twice lower. An insignificant increase in CHR concentration at $75 \%$ humidity in contrast to $50-75 \%$ humidity $(0.03$ $\mu \mathrm{g} / \mathrm{kg}$ ) was observed. The examination of the smoking of the ham at pressure below $1000 \mathrm{hPa}$ and humidity above $50 \%$ shows that CHR content was significantly lower and amounted on average to 6.50 $\mu \mathrm{g} / \mathrm{kg}$. It is worth underlining that in the remaining ranges of relative humidity at pressure below 1000 $\mathrm{hPa}$, chrysene concentration was nearly twice lower in comparison to the concentration of this $\mathrm{PAH}$ in the product smoked at relative humidity below $50 \%$. An increase in the relative air humidity had a favourable influence on the quality of the consolidated product by significantly decreasing PAH contamination. Among the analysed PAHs, a significant reduction in benzo(a)anthracene content, a light hydrocarbon, was observed with an increase in air humidity (Guillen et al., 2000b; Jira, 2004). A decrease in benzo(a)anthracene content should be considered as particularly favourable since this compound was present in the examined product at a high concentration (Table 3 ). It is also worth noting the changes in chrysene concentration, which, analogically to benzo(a)anthracene, is always present in traditionally smoked products and often at a high concentration (Guillen, Sopelana, 1997; Stumpe-Viksna et al., 2008; Leroy et al., 2013; Rose et al., 2015; Li et al., 2016). Although a significant influence of air humidity or of atmospheric pressure during smoking was not observed, it is worth noting that the average CHR concentration exceeded the value of $5.00 \mu \mathrm{g} / \mathrm{kg}$ at humidity below $50 \%$ and pressure above $1000 \mathrm{hPa}$. The contamination level above $5.00 \mu \mathrm{g} / \mathrm{kg}$ is considered particularly dangerous to consumers' health (Leroy et al., 2013; Rose et al., 2015; Li et al., 2016).

Results concerning the content of heavy PAHs are presented in Tables 4 and 5. It was observed that 5methylchrysene content depended on air humidity during smoking. A statistically significant interaction between atmospheric pressure and relative air humidity was also observed (Tab. 4). The obtained results show that smoking in the conditions of low air humidity, (below 50\%), resulted in a twice higher 5-MeCHR content if the atmospheric pressure was below $1000 \mathrm{hPa}$. Average 5 -MeCHR content was $1.30 \mu \mathrm{g} / \mathrm{kg}$ and $0.71 \mu \mathrm{g} / \mathrm{kg}$, respectively. An increase in air humidity to $50-75 \%$, regardless of the pressure levels, led to a decrease in $5-\mathrm{MeCHR}$ concentration to an average level of $0.62-0.69 \mu \mathrm{g} / \mathrm{kg}$. It is worth noting that in the conditions of high air humidity and simultaneous low atmospheric pressure, a further decrease in 5MeCHR content to $0.21 \mu \mathrm{g} / \mathrm{kg}$ was observed. 
Table 3. Benzo(a)anthracene content in traditional Polish pork ham smoked using the traditional method depending on relative air humidity and atmospheric pressure during smoking

\begin{tabular}{|c|c|c|c|c|c|c|c|c|c|}
\hline & & & & \multicolumn{6}{|c|}{ MANOVA } \\
\hline \multirow[t]{3}{*}{ Pressure } & \multirow[t]{3}{*}{ Humidity } & \multirow{2}{*}{\multicolumn{2}{|c|}{$\mathrm{BaA}$ content $[\mu \mathrm{g} / \mathrm{kg}]$}} & \multicolumn{6}{|c|}{ Effect } \\
\hline & & & & \multicolumn{2}{|c|}{ Pressure } & \multicolumn{2}{|c|}{ Humidity } & \multicolumn{2}{|c|}{ Press.*Humid. } \\
\hline & & $\bar{x}$ & $\mathrm{~S}_{\mathrm{d}}$ & $\mathrm{F}$ & $\mathrm{p}$ & $\mathrm{F}$ & $\mathrm{p}$ & $\mathrm{F}$ & $p$ \\
\hline \multirow[t]{3}{*}{$>1000 \mathrm{hPa}$} & $<50 \%$ & 3,87 & 1,14 & \multirow[t]{6}{*}{1,42} & \multirow[t]{6}{*}{0,24} & \multirow[t]{6}{*}{1,47} & \multirow[t]{6}{*}{0,24} & \multirow[t]{6}{*}{0,32} & \multirow[t]{6}{*}{0,73} \\
\hline & $50-75 \%$ & 1,52 & 1,47 & & & & & & \\
\hline & $>75 \%$ & 1,70 & 1,80 & & & & & & \\
\hline \multirow[t]{3}{*}{$<1000 \mathrm{hPa}$} & $<50 \%$ & 4,31 & 1,04 & & & & & & \\
\hline & $50-75 \%$ & 3,72 & 0,68 & & & & & & \\
\hline & $>75 \%$ & 2,61 & 0,81 & & & & & & \\
\hline \multirow[t]{4}{*}{$>1000 \mathrm{hPa}$} & & & & \multicolumn{6}{|c|}{ ANOVA } \\
\hline & $<50 \%$ & 3,87 & 1,14 & & & \multirow[t]{3}{*}{3,34} & \multirow[t]{3}{*}{0,035} & & \\
\hline & $50-75 \%$ & 1,52 & 1,47 & & & & & & \\
\hline & $>75 \%$ & 1,70 & 1,80 & & & & & & \\
\hline
\end{tabular}

Table 4. The analysed PAHs content in traditional Polish pork ham smoked using the traditional method depending on relative air humidity and atmospheric pressure during smoking

\begin{tabular}{|c|c|c|c|c|c|c|c|c|c|c|c|c|c|c|c|c|c|c|c|c|}
\hline & \multirow[t]{2}{*}{ Pressure } & \multirow[t]{2}{*}{ Humidity } & \multicolumn{2}{|c|}{$\begin{array}{c}\text { CHR } \\
\text { content } \\
{[\mu \mathrm{g} / \mathrm{kg}]}\end{array}$} & \multicolumn{2}{|c|}{$\begin{array}{c}\text { 5-MeCHR } \\
\text { content } \\
{[\mu \mathrm{g} / \mathrm{kg}]}\end{array}$} & \multicolumn{2}{|c|}{$\begin{array}{c}\text { BaP content } \\
{[\mu \mathrm{g} / \mathrm{kg}]}\end{array}$} & \multicolumn{2}{|c|}{$\begin{array}{c}\text { BbF content } \\
{[\mu \mathrm{g} / \mathrm{kg}]}\end{array}$} & \multicolumn{2}{|c|}{$\begin{array}{l}\text { BghlP } \\
\text { content } \\
{[\mu \mathrm{g} / \mathrm{kg}]}\end{array}$} & \multicolumn{2}{|c|}{$\begin{array}{c}\text { BjF content } \\
{[\mu \mathrm{g} / \mathrm{kg}]}\end{array}$} & \multicolumn{2}{|c|}{$\begin{array}{c}\text { BkF content } \\
{[\mu \mathrm{g} / \mathrm{kg}]}\end{array}$} & \multicolumn{2}{|c|}{$\begin{array}{c}\mathrm{BcFl} \\
\text { content } \\
{[\mu \mathrm{g} / \mathrm{kg}]}\end{array}$} & \multicolumn{2}{|c|}{$\begin{array}{c}\text { IcdP } \\
\text { content } \\
{[\mu \mathrm{g} / \mathrm{kg}]}\end{array}$} \\
\hline & & & $\bar{x}$ & $\mathrm{~S}_{\mathrm{d}}$ & $\bar{x}$ & $\mathrm{~S}_{\mathrm{d}}$ & $\bar{x}$ & $\mathrm{~S}_{\mathrm{d}}$ & $\bar{x}$ & $\mathrm{~S}_{\mathrm{d}}$ & $\bar{x}$ & $\mathrm{sd}$ & $\bar{x}$ & $\mathrm{sd}$ & $\bar{x}$ & sd & $\bar{x}$ & sd & $\bar{x}$ & $\mathrm{sd}$ \\
\hline \multirow{3}{*}{\multicolumn{2}{|c|}{$>1000 \mathrm{hPa}$}} & $<50 \%$ & 5,09 & 1,28 & 0,71 & 0,17 & 2,01 & 0,36 & 0,44 & 0,26 & 0,93 & 0,15 & 0,16 & 0,19 & 0,33 & 0,31 & 2,41 & 1,16 & 0,34 & 0,2 \\
\hline & & $50-75 \%$ & 2,63 & 1,65 & 0,62 & 0,23 & 1,17 & 0,07 & 0,33 & 0,26 & 0,51 & 0,19 & 0,11 & 0,1 & 0,15 & 0,11 & 1,35 & 1,10 & 0,22 & 0,17 \\
\hline & & $>75 \%$ & 2,66 & 2,02 & 0,43 & 0,18 & 1,06 & 0,08 & 0,66 & 0,36 & 0,49 & 0,24 & 0,41 & 0,31 & 0,34 & 0,3 & 2,96 & 1,84 & 0,25 & 0,13 \\
\hline \multirow{3}{*}{\multicolumn{2}{|c|}{$<1000 \mathrm{hPa}$}} & $<50 \%$ & 6,5 & 1,17 & 1,3 & 0,16 & 2,51 & 0,33 & 1,18 & 0,25 & 1,19 & 0,14 & 0,62 & 0,22 & 0,34 & 0,29 & 2,58 & 1,06 & 0,57 & 0,09 \\
\hline & & $50-75 \%$ & 3,28 & 0,76 & 0,69 & 0,1 & 1,27 & 0,22 & 0,98 & 0,21 & 0,6 & 0,09 & 0,45 & 0,19 & 0,53 & 0,19 & 2,05 & 0,49 & 0,38 & 0,08 \\
\hline & & $>75 \%$ & 3,55 & 0,9 & 0,21 & 0,03 & 1,17 & 0,26 & 0,49 & 0,33 & 0,49 & 0,11 & 0,36 & 0,29 & 0,69 & 0,22 & 3,52 & 0,82 & 0,22 & 0,12 \\
\hline \multirow{6}{*}{ 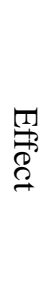 } & \multirow{2}{*}{ Pressure } & $\mathrm{F}$ & \multicolumn{2}{|c|}{1,2} & \multicolumn{2}{|c|}{0,90} & \multicolumn{2}{|c|}{2,13} & \multicolumn{2}{|c|}{1,69} & \multicolumn{2}{|c|}{0,81} & \multicolumn{2}{|c|}{0,82} & \multicolumn{2}{|c|}{0,81} & \multicolumn{2}{|c|}{0,65} & \multicolumn{2}{|c|}{1,09} \\
\hline & & $\mathrm{p}$ & \multicolumn{2}{|c|}{0,255} & \multicolumn{2}{|c|}{0,349} & \multicolumn{2}{|c|}{0,154} & \multicolumn{2}{|c|}{0,202} & \multicolumn{2}{|c|}{0,372} & \multicolumn{2}{|c|}{0,370} & \multicolumn{2}{|c|}{0,374} & \multicolumn{2}{|c|}{0,426} & 0,3 & 303 \\
\hline & Humidity & $\mathrm{F}$ & 5, & & 6,6 & & 3,1 & & 0 , & & & & 0, & & & 05 & & & 3,2 & $24^{*}$ \\
\hline & 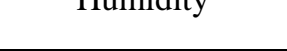 & $\mathrm{p}$ & $\mathbf{0 , 0}$ & & $\mathbf{0 , 0}$ & & $\mathbf{0 , 0}$ & & 0, & & & & 0,9 & & 0, & 51 & & 12 & $\mathbf{0 , 0}$ & 41 \\
\hline & & $\mathrm{F}$ & 0,8 & & 3,3 & & 0, & & 0 , & & & & 0, & & & 37 & & 44 & 0 , & 54 \\
\hline & Pressure-Humidity & $\mathrm{p}$ & 0,4 & & $\overline{\mathbf{0 , 0}}$ & & 0,8 & & 0, & & & & 0,7 & & 0, & 91 & & 44 & & 586 \\
\hline
\end{tabular}

The * symbol by the F statistic value signifies a significant influence of the effect at a $\alpha=0,05(p<0,05)$ significance level 
In the conditions of high pressure the observed decrease was significantly smaller than $0.43 \mu \mathrm{g} / \mathrm{kg}$. The statistical analysis showed that benzo(a)pyrene content in traditional Polish pork ham depended only on relative air humidity (Table 4).

A statistically significant decrease in BaP content together with an increase in air humidity was observed in both groups of atmospheric pressure. At relative humidity below $50 \%$ the contamination was 1.91 and $2.51 \mu \mathrm{g} / \mathrm{kg}$ on average. In $50-75 \%$ humidity range it decreased to an average level of 1.17 and $1.27 \mu \mathrm{g} / \mathrm{kg}$. Humidity above $75 \%$ led to a further decrease in $\mathrm{BaP}$ concentration in the examined traditional pork ham. It is worth observing that at pressure below $1000 \mathrm{hPa}$ and humidity above $50 \%, \mathrm{BaP}$ content exceeded the level allowed by the European Commission, that is above $2 \mu \mathrm{g} / \mathrm{kg}(2.51 \mu \mathrm{g} / \mathrm{kg})$.

Benzo(b)fluoranthene content in traditional Polish pork ham did not depend on the interplay between air humidity and atmospheric pressure during smoking (Table 4).

However, a single-factor variance analysis showed that with relative air humidity below 50\%, a statistically significant influence of atmospheric pressure $(\mathrm{F}=3.15 ; \mathrm{p}=0.041)$ was observed. Average $\mathrm{BbF}$ content in the ham smoked in the conditions of high pressure was around three times lower than in the ham smoked in the time when the pressure was lower than $1000 \mathrm{hPa}(0.44 \mu \mathrm{g} / \mathrm{kg}$ and $1.18 \mu \mathrm{g} / \mathrm{kg}$, respectively) (Table 5). At relative air humidity between $50-75 \%$ the influence of atmospheric pressure was also statistically confirmed $(F=2.29 ; p=0.048)$, while the range of the observed changes in $\mathrm{BbF}$ concentration in the examined product, as with humidity below $50 \%$, was nearly three times higher.

The data in Table 4 show that BghiP content in traditional Polish pork ham depended only on air humidity. A high BghiP content in the ham smoked at humidity below 50\% in both groups of atmospheric pressure is worth noting, i.e. $=0.93$ and $1.19 \mu \mathrm{g} / \mathrm{kg}$, respectively. An increase in relative humidity contributed to a decrease in the accumulation of BghiP in ham by around $50 \%$. This phenomenon was observed at pressure below and above $1000 \mathrm{hPa}$.

An influence of the examined microclimatic conditions on benzo(j)fluoranthene content was not observed. It was shown, however, that the highest contamination level $(0.62 \mu \mathrm{g} / \mathrm{kg} \mathrm{BjF})$ was present in the ham smoked at humidity below $50 \%$ and pressure above $1000 \mathrm{hPa}$ (Table 4).

It was also shown that $\mathrm{BkF}$ and $\mathrm{BcFl}$ concentration did not depend on the examined factors (Tables 4, 5). For both hydrocarbons, a particularly high standard deviation value pointing to a significant variability in the concentration of these compounds in the examined product was observed. As regards these compounds, another interesting relation was also observed - in both groups of atmospheric pressure, at $50-75 \%$ humidity, a decrease in their concentration was recorded in comparison to the ham smoked at humidity below $50 \%$. At humidity above $75 \%$, average $\mathrm{BkF}$ and $\mathrm{BcFl}$ concentration increased in both pressure groups.

The study did not show an influence of atmospheric pressure on IcdP; its content depended on relative air humidity (Table 4). IcdP decreased with an increase in air humidity, which was observed in both ranges of atmospheric pressure. At humidity below $1000 \mathrm{hPa}$, a decrease by $0.35 \mu \mathrm{g} / \mathrm{kg}$ was observed, whereas at humidity above $1000 \mathrm{hPa}$, a decrease by $0.11 \mu \mathrm{g} / \mathrm{kg}$ was recorded.

A favourable influence of the increase in relative humidity on the decrease in the concentration of heavy hydrocarbons should also be underlined. An increase in humidity led to a significantly meaningful decrease in the contamination of the examined product with 5-methylchrysene. The decrease was observed in particular at low atmospheric pressure.

Benzo(a)pyrene concentration also depended on relative air humidity. It should be considered as an especially meaningful observation because this compound is regarded as particularly toxic. For these reasons the Regulation of the European Commission (UE) No. 835/2011 specified that the maximum concentration of this compound in smoked products should be below $2 \mu \mathrm{g} / \mathrm{kg}$.

Table 5. Benzo(b)fluoranthene content in traditional Polish pork ham smoked using the traditional method depending on relative air humidity and atmospheric pressure during smoking ANOVA

\begin{tabular}{|c|c|c|c|c|c|}
\hline \multirow[t]{2}{*}{ Humidity } & \multirow[t]{2}{*}{ Pressure } & \multicolumn{2}{|c|}{ BbF content $[\mu \mathrm{g} / \mathrm{kg}]$} & \multirow{2}{*}{$\mathrm{F}$} & \multirow{2}{*}{$\mathrm{p}$} \\
\hline & & $\bar{x}$ & $\mathrm{~S}_{\mathrm{d}}$ & & \\
\hline \multirow[t]{2}{*}{$<50 \%$} & $>1000 \mathrm{hPa}$ & 0,44 & 0,26 & \multirow{2}{*}{3,15} & \multirow{2}{*}{0,041} \\
\hline & $<1000 \mathrm{hPa}$ & 1,18 & 0,25 & & \\
\hline \multirow[t]{2}{*}{$50-75 \%$} & $>1000 \mathrm{hPa}$ & 0,33 & 0,26 & \multirow{2}{*}{2,29} & \multirow{2}{*}{0,048} \\
\hline & $<1000 \mathrm{hPa}$ & 0,98 & 0,21 & & \\
\hline \multirow[t]{2}{*}{$>75 \%$} & $>1000 \mathrm{hPa}$ & 0,66 & 0,36 & \multirow{2}{*}{0,23} & \multirow{2}{*}{0,514} \\
\hline & $<1000 \mathrm{hPa}$ & 0,49 & 0,33 & & \\
\hline
\end{tabular}


In previous studies it was shown that $\mathrm{BaP}$ concentration in a traditionally smoked product was as high as $4.03 \mu \mathrm{g} / \mathrm{kg}$ on average.

As the conducted experiment showed, products smoked at air humidity below $50 \%$ also contained above $2 \mu \mathrm{g} / \mathrm{kg}$ of BaP. At a higher level of humidity, b(a)p concentration was almost twice smaller.

The study also showed a significant interaction between the influence of humidity and atmospheric pressure conditioning the content of three PAHs classified as heavy compounds, i.e. benzo(a)pyrene, benzo(b)fluoranthene and indeno(c,d)pyrene. A statistically significant decrease in the contamination of the ham with benzo(a)anthracene occurred together with an increase in relative air humidity, at a high atmospheric pressure. An increase in relative air humidity during an atmospheric low had a favourable influence on the contamination of the ham with benzo(b)fluoranthene and indeno(c,d)pyrene.

In the case of benzo(k)fluoranthene and benzo(c)fluorene, a significant variability in the concentration, associated with atmospheric conditions during smoking, was observed. The highest concentrations of these compounds were observed in the ham smoked at atmospheric pressure not exceeding $1000 \mathrm{hPa}$ and relative air humidity below $75 \%$. Despite a reverse trend in the concentration changes of these two compounds, depending primarily on relative air humidity, the study showed that the concentration of most of the analysed hydrocarbons decreases at a high pressure.

\section{CONCLUSIONS}

The research indicated a statistically significant impact of selected meteorological conditions during the smoking process on polycyclic aromatic hydrocarbon content in traditional Polish pork ham.
Presumably, atmospheric conditions, in particular relative air humidity and to some extent atmospheric pressure during smoking, may influence the degree of purity of the obtained products associated with PAH content by diminishing the content of toxic polycyclic aromatic hydrocarbons. The obtained information on the influence of atmospheric conditions on the content of harmful PAHs in smoked meat products constitutes a further factor which should be considered during smoking.

The results show that the conditions which are conducive to a decrease in the content of dangerous compounds, such as PAHs, comprise smoking when relative air humidity is at a level above $75 \%$ and atmospheric pressure is high.

According to literature, the indicated correlation may be associated with the amount of the smoking aerosol flowing through the smoking chamber and the pyrolysis temperature of the wood used. As stated by authors (Šimko, 2005; Škaljac et al. 2014; Rozentāle et al., 2015), the conditions of high atmospheric pressure and low relative humidity are conducive to an intensive wood burning and strengthen the air draught in the smoking chamber. As a result, the amount of dangerous compounds, including PAHs, present in the smoke and later deposited in the products, increases. A high temperature of wood pyrolysis, a condition typical of atmospheric highs, also contributes to a higher PAH concentration in the smoke.

It was observed that an increase in relative humidity and in atmospheric pressure led to a reduction in PAH content in the examined product.

It was also stated that traditional smoking conducted in the conditions of high relative air humidity and high atmospheric pressure contributed to a decrease mainly in 5-methylchrysene, benzo(a)pyrene and benzo(g,h,i)perylene.

\section{REFERENCES}

1. Alomirah, H., Al-Zenki S., Al-Hooti S., Zaghloul S., Sawaya W., Ahmed N. \& Kannan K. (2011). Concentrations and dietary exposure to polycyclic aromatic hydrocarbons (PAHs) from grilled and smoked foods. Food Control 22, 2028-2035. doi: 10.1016 / j.foodcont.2011.05.024.

2. Alomirah, H., Al-Zenki S., Husain A., Sawaya W., Ahmed N., Gevao B. \& Kannan K. (2010). Benzo[a]pyrene and total polycyclic aromatic hydrocarbons (PAHs) levels in vegetable oils and fats do not reflect the occurrence of the eight genotoxic PAHs. Food Additives and Contaminants 27, 869-878. doi: $10.1080 / 19440040903493793$.

3. Arias, A.H., Vazquez-Botello A., Tombesi N., Ponce-Vélez G., Freije H. \& Marcovecchio J. (2010). Presence distribution and origins of polycyclic aromatic hydrocarbons (PAHs) in sediments from Bahía Blanca estuary. Argentina Environmental Monitoring and Assessment 160, 301-314. doi: 10.1007/s10661-008-0696-5 
4. Bagnowska, A., Mostowski R., Trzęsowska A. \& Krala L. (2011). Techniczne, technologiczne i zdrowotne aspekty wędzenia mięsa [Technical, technological and health safety aspects smoking of meat]. Acta Scientarum Technica Agraria 10 (1-2), 33-40.

5. Choroszy, K. \& Tereszkiewicz K. (2020). Polycyclic aromatic hydrocarbon content in sausage smoked using a polish traditional method. Afr. J. Food Agric. Nutr. Dev. 20(4), 16143-16160.

6. Djinovic, J., Popovic A. \& Jira W. (2008). Polycyclic aromatic hydrocarbons (PAHs) in different types of smoked meat products from Serbia. Meat Science 80 (2), 449-456. doi: 10.1016/j.meatsci.2008.01.008

7. Dobosz, M. (2010). Wspomagana komputerowo statystyczna analiza wyników badań. Warszawa: Akademicka Oficyna Wydawnicza EXIT.

8. Ekomy, A. S., Bruneau D., Mbega D. J. \& Aregba W. (2013). Nouveau concept de séchage et de fumage artisanal des aliments: Application en milieu de pêche artisanale au Gabon. Afrique Science, 9(3), 45-55.

9. Fasano, E., Yerba-Pimentel I. \& Martinez-Carballo E. (2016). Proofing, distribution and levels of carcinogenic polycyclic aromatic hydrocarbons in traditional smoked plant and animal foods. Food Control, 59, 581-590. https://doi.org/10.1016/j.foodcont.2015.06.036.

10. Ghasemzadeh-Mohammadi, V., Mohammadi A., Hashemi M., Khaksar R. \& Haratian P. (2012). Microvawe-assisted extraction and dispersive liquid-liquid microextraction followed by gas chromatography-mass spectrometry for isolation and determination of polycyclic aromatic hydrocarbons in smoked fish. Journal of Chromatography. A, 1237, 30-36. DOI: 10.1016 / j.chroma.2012.02.078

11. Guillen, M.D. \& Sopelana P. (1997). Polycyclic aromatic hydrocarbons in diverse foods reviews on. Journal of Environmental Health, 12, 133-145. DOI: 10.1515 / reveh.1997.12.3.133

12. Guillen M.D., Sopelana P. \& Partearroyo M.A. (2000b). Determination of polycyclic aromatic hydrocarbons in commercial liquid smoke flavourings of different compositions by gas chromatography - mass spectrometry. Journal of Agricultural and Food Chemistry. 48, 126-31. doi.org/10.1021/jf9908998.

13. Jira W. (2004). AGC-MS method for the determination of carcinogenic polycycic aromatic hydrocarbons (PAH) in smoked meat products and liquid smokes. Eur. Food Research and Technology. 218, 208-212.

14. Guo, W., He M., Yang Z., Lin C., Quan X. \& Men B. (2009). Distribution, partitioning and sources of polycyclic aromatic hydrocarbons in Daliao River water system in dryseason. China Journal of Hazard Materials, 164, 1379-1385. doi:10.1016/j.jhazmat.2008.09.083

15. Hitzel, A., Pöhlmann M., Schwägele F., Speer K. \& Jira W. (2012). Polycyclic Aromatic Hydrocarbons (PAH) and phenolic substances in cold smoked sausages depending on smoking conditions using smoldering smoke. Journal of Food Research, 1, 14-19.

16. Kołakowski, et al. (2012). Technologia wędzenia żywności. Warszawa: PWRiL.

17. Ledesma, E., Rendueles M. \& Díaz M. (2014). Benzo(a)pyrene penetration on a smoked meat product during smoking time. Food Additives and Contaminants, A, 31 (10), 1688-1698.

18. Ledesma, E., Rendueles M. \& Díaz M. (2015). Spanish smoked meat products: Benzo(a)pyrene (BaP) contamination and moisture. Journal of Food Composition and Analysis, 37, 87-94. DOI: 10.1016 / j.jfca.2014.09.004.

19. Ledesma, E., Rendueles M. \& Díaz M. (2017). Smoked food. Current Developments in Biotechnology and Bioengineering, 1, 201-243.

20. Lee, J.-G., Kim S.-Y., Moon J.-S., Kim S.-H. \& Kang D.-H. (2016). Effects of grilling procedures on levels of polycyclic aromatic hydrocarbons in grilled meats. Food Chemistry, 199, 632-638. doi.org/10.1016/j.foodchem.2015.12.017.

21. Leroy, F., Geyzen A., Janssens M., De Vuyst L. \& Scholliers P. (2013). Meat fermentation at the crossroads of innovation and tradition: a historical outlook. Trends in Food Science and Technology, 31 (2), 130-137. doi: 10.1016 / j.tifs.2013.03.008.

22. Li, X. (2016). Metal food packaging design based on hazard analysis critical control point (HACCP) system in canned food safety. Acta Universitatis Cibiniensis. Series E: Food Technology, 20(1), 93-104. doi.org/10.1515/aucft-2016-0008

23. Li, J., Dong H., Han B., Zhu Ch. \& Zhang D. (2016). Quantitatively assessing the health risk of exposure to PAHs from intake of smoked meats. Ecotoxicology and Environmental Safety, 124, 91-95.

24. Migdał, W. (2015). Sterowanie jakościa produktów pochodzenia zwierzęcego. [Management of the quality of products of animal origin]. Przeglad Hodowlany, 5, 1-8.

25. Mynarski S. (2003). Analiza danych rynkowych i marketingowych z wykorzystaniem programu Statistica. Kraków: Wyd. AE.

26. McMurry J. (2005). Chemia organiczna. T. 4. Warszawa: PWN.

27. Norinaga K., Janardhanan V. M. \& Deutschmann O. (2008). Detailed chemical kinetic modeling of pyrolysis of ethylene, acetylene, and propylene at 1073-1373 K with a plug-flow reactor model. International Journal of Chemical Kinetics, 40, 199-208. doi.org/10.1002/kin.20302. 
28. Parol, J., Pietrzak-Fiećko R. \& Smoczyński S. (2014). Wielopierścieniowe węglowodory aromatyczne (WWA) w wędzonym pstrągu tęczowym (Oncrhynchus Mykiss) [Polycyclic aromatic hydrocarbons (PAHs) in smoked rainbow trout (Oncorhynchus Mykiss)]. Żywność. Nauka. Technologia. Jakość, 6(97), 125-137. doi: 10.15193/zntj/2014/97/125-137

29. Pöhlmann, M., Hitzel A., Schwägele F., Speer K. \& Jira W. (2012). Contens of polycyclic aromatic hydrocarbons (PAH) and phenolic substances in Frakfurter-type sausages depending on smoking conditions using glow smoke. Meat Science, 90(1), 176-84. doi: 10.1016 / j.meatsci.2011.06.024.

30. Pongpiachan, S. (2015). A preliminary study of using polycyclic aromatic hydro-carbons as chemical tracers for traceability in soybean products. Food Control, 47, 392-400. doi.org/10.1016/j.foodcont.2014.07.032.

31. Rey-Salgueiro, L., Martínez-Carballo E., García-Falcón M.S., González-Barreiro C. \& Simal-Gándara J. (2009b). Occurrence of polycyclic aromatic hydrocarbons and their hydroxylated metabolites in infant foods. Food Chemistry, 115, 814-819.

32. Rey-Salgueiro, L., Martínez-Carballo E., García-Falcón M.S. \& Simal-Gándara, J. (2009a). Survey of polycyclic aromatic hydrocarbons in canned bivalves and investigation of their potential sources. Food Research International, 42, 983-988.

33. Rey-Salgueiro, L., García-Falcón M. S., Martínez-Carballo E., González-Barreiro C. \& Simal-Gándara J. (2008a). The use of manures for detection and quantification of polycyclic aromatic hydrocarbons and 3hydroxybenzo[a]pyrene in animal husbandry. The Science of the Total Environment, 406(1-2), 279-286. https://doi.org/10.1016/j.scitotenv.2008.07.059.

34. Rey-Salgueiro, L., Martínez-Carballo E., García-Falcón M. S. \& Jesús Simal-Gándara J. (2008b). Effects of a chemical company fire on the occurrence of polycyclic aromatic hydrocarbons in plant foods. Food Chemistry, 108(1), 347-353. https://doi.org/10.1016/j.foodchem.2007.10.042.

35. Rose, M., Holland J., Dowding A., Petch S., White S., Fernandes A. \& Mortimer D. (2015). Investigation into the formation of PAHs in foods prepared in the home to determine the effects of frying, grilling, barbecuing, toasting and roasting. Food and Chemical Toxicology, 78, 1-9. doi: 10.1016 / j.fct.2014.12.018.

36. Rozentāle, I., Stumpe-Viksna I., Začs D., Siksna I. \& Melngaile A. (2015). Assessment of dietary exposure to polycyclic aromatic hydrocarbons from smoked meat products produced in Latvia. Food Control, 54, 16-22. doi.org/10.1016/j.foodcont.2015.01.017.

37. Sapota, A. (2002). Wielopierścieniowe węglowodory aromatyczne (substancje smołowe rozpuszczalne w cykloheksanie) [Polycyclic aromatic hydrocarbons]. Podstawy i Metody Oceny Środowiska Pracy, 2(32), 179-208.

38. Shrestha, B., Anderson T.A., Acosta-Martinez V., Payton P. \& Cañas-Carrell J.E. (2015).The influence of multiwalled carbon nanotubes on polycyclic aromatic hydrocarbon (PAH) bioavailability and toxicity to soil microbial communities in alfalfa rhizosphere. Ecotoxicology and Environmental Safety, 116, 143149. doi: 10.1016 / j.ecoenv.2015.03.005.

39. Šimko, P. (2005). Factors affecting elimination of polycyclic aromatic hydrocarbons from smoked meat foods and liquid smoke flavorings. Molecular Nutrition and Food Research, 49(7), 639-647. doi: 10.1002 / mnfr.200400091.

40. Škaljac, S. Petrović L., Tasić T., Ikonić P., Jokanović M., Tomović V., Džinić N., Šojić B., Tjapkin A. \& Škrbić B. (2013). Influence of smoking in traditional and industrial conditions on polycyclic aromatic hydrocarbons content in dry fermented sausages from Serbia. Food Control, 40, 12-18. doi.org/10.1016/j.foodcont.2013.11.024.

41. Stumpe-Viksna, I., Bartkevics V., Kukare A. \& Morozovs A. (2008). Polycyclic aromatic hydrocarbons in meat smoked with different types of wood. Food Chemistry, 110(3), 794-797. doi.org/10.1016/j.foodchem.2008.03.004

42. Singh, L., Varshney J. G. \& T. Agarwal. (2016). Polycyclic aromatic hydrocarbons' formation and occurrence in processed food. Food Chemistry, 199(2016), 768-781.

doi.org/10.1016/j.foodchem.2015.12.074

43. Yebra-Pimentel, I., Fernández-González R., Carballo E.M. \& Simal-Gándara J. (2012). Searching ingredients polluted by polycyclic aromatic hydrocarbons in feeds due to atmospheric or pyrolytic sources. Food Chemistry, 135(3), 2043-2051.

44. Yebra-Pimentel, I., Fernández-González R., Martínez-Carballo E. \& Simal-Gándara J. (2014). Optimization of purification processes to remove polycyclic aromatic hydrocarbons(PAHs) in pollute draw fish oils. Science of the Total Environment, 470-471C, 917-924. doi: 10.1016 /j.scitotenv.2013.10.061 